This is a post-refereeing final draft. When citing, please refer to the published version: Cohen, E. and Cohen, S.A. (2012). Current sociological theories and issues in tourism. Annals of Tourism Research, 39(4), 2177-2202. DOI: 10.1016/j.annals.2012.07.009

\title{
Current Sociological Theories and Issues in Tourism
}

Erik Cohen

Dept. of Sociology and Anthropology, The Hebrew University of Jerusalem, Israel

Scott A. Cohen

School of Hospitality and Tourism Management, University of Surrey, United Kingdom

\begin{abstract}
This article reviews the changing nature of contemporary tourism and sociological approaches to its study. We examine the broad social trends and specific historical events that recently affected tourism and discuss how the focus of sociological inquiry in tourism studies shifted from earlier discourses of authenticity and the tourist gaze to three novel theoretical approaches, the mobilities "paradigm", the performativity approach and actor-network theory (ANT), which each reflect a broader metatheoretical re-orientation in contemporary philosophy and sociology. We appraise these conceptual developments and discuss their limitations. We then identify several current research issues as important areas for problem-oriented work at the intersections of tourism and contemporary society: social justice, environmental sustainability, natural disasters, terrorism, heritage, embodiment and affect, and mediatization.
\end{abstract}

Keywords: social trends, authenticity, mobilities, performativity, actor-network theory, current issues

\section{INTRODUCTION}

The last quarter century has been marked by dramatic historical events, major technological innovations and far-reaching social and cultural changes in both the Western and non-Western parts of the world. In their wake, the nature of tourism, its relationship with society, as well as the sociological approaches to its analysis and interpretation, underwent a widespread transformation. The contemporary world is marked by a high degree of fluidity or "liquidity" (Bauman, 2000). It is a world of accelerated economic, social and cultural change, driven by the process of globalization, rapid technological progress, and the communication and information revolutions. These forces led to an increase in the tempo of life, a collapse of time and space, a cultural pluralization, a de-differentiation of social domains, and a 
fragmentation of lifestyles. While these trends seemingly engendered growing global affluence, they were also accompanied, on the one hand, by a pervasive consumerism and a commoditization of virtually all domains of life, and on the other hand, by an increasing sense of risk (Beck, 1992) and personal insecurity, in a world of fluctuating relationships, uncertain life chances, and a "post-modern" trend of philosophical skepticism.

The last quarter century was also marked by some major historical events, which either strengthened or resisted those basic trends, and thereby significantly affected the global dynamics of contemporary tourism. The principal benchmark events of this period can be summarized as follows: One, the collapse of the Soviet Union and of the East European communist regimes, and the subsequent transformation of China and Vietnam into post-communist societies. The stagnant life and cultures of these huge regions were subsequently opened to inbound, mostly Western, tourism, whereas their flourishing liberalized economies engendered a growing flow of outbound tourism into their neighboring countries and to the West.

Two, the relocation of the focus of economic growth from the West to the "emergent economies" of non-Western countries, primarily in Asia (China, India, South Korea, Hong Kong, Singapore), but also in Latin America (Brazil). This enabled growing numbers of their middle-classes to travel, leading to a phenomenal expansion of domestic tourism, especially in Asia, a growth of intra-regional tourism, and a significant change in the composition of international tourism on the global level. Tourism thus ceased to be a primarily Western phenomenon, but became fully internationalized. Three, the Asian financial crisis of 1997, and the 2007-8 and 201012 global financial crises, which affected the world's economic stability and exasperated the personal financial security of the heretofore prosperous Western middle classes, reduced their spending power, and provoked a slowdown in the rate of expansion of global international tourism (E. Cohen, 2012).

Four, the September 11, 2001 attacks in the U.S., which dramatically highlighted the rise of militant fundamentalist Islam (and provoked the wars in Afghanistan and Iraq), followed by terrorist attacks on tourist facilities elsewhere, highlighted the interface between tourism and terrorism, aggravated the sense of risk in travel, and led to ever more stringent security procedures in global tourism, which put increasing constraints on the comfort, ease, and freedom of travel. Five, the catastrophic natural disasters, which struck the world in the last decade, such as the Indian Ocean tsunami in 2004, Hurricane Katrina, and the tsunami following the earthquake in East Japan, not only affected some major tourist destinations (e.g. the Thai Andaman coast, or New Orleans) and caused increased apprehension of traveling into disaster-prone areas, but also demonstrated the vulnerability and helplessness of tourists once the institutional structures on which they depend break down.

These broad social trends and dramatic historical events thoroughly affected the scope, origins and destinations of tourist flows, the motives and styles of travel, the structure of the tourist industry, and the relationship between tourism and ordinary life. They also impacted the modes of sociological thinking about tourism, the paradigmatic and theoretical approaches to it, and the choice of current research issues, to be discussed in the body of this article. 


\section{CONCEPTUAL AND THEORETICAL DEVELOPMENTS}

Limitations of space preclude an exhaustive discussion of the multiplicity of approaches in sociology and anthropology to the study of tourism. Sociological theorizing about tourism during the last quarter of the $20^{\text {th }}$ century was dominated by the question of the relationship between tourism and (Western) modernity (MacCannell, 1973; 1976; Wang, 2000), and particularly by the issue of authenticity as a cultural motive, albeit motivating individuals to varying degrees of intensity (E. Cohen, 1979), in tourist experience. Stated originally in MacCannell's (1973) seminal article in terms of "staged authenticity," the twin arguments that moderns seek authenticity outside modernity, and that locals stage it for them, appeared to have the potential to become the basis of a paradigm for the sociological study of tourism. Instead, the discourse turned to the elucidation of the multiple meanings of "authenticity" (e.g. Bruner, 2005a; E. Cohen, 2007), and split up into sub-discourses around the three types of authenticity discerned by Wang $(1999 ; 2000)$ : "objective (object)" authenticity (Reisinger \& Steiner, 2006), "constructed" authenticity (E. Cohen, 1988; Olsen, 2002; Cook, 2010) and "subjective (existential)" authenticity (Cary, 2004; Steiner \& Reisinger, 2006; Cook 2010). The discourse of authenticity eventually fractured into a plethora of further sub-types, as in Knudsen and Waade's (2010) edited volume, a collective effort to "re-invest" authenticity from a primarily performative approach. Recently, Cohen and Cohen (2012) suggested shifting from a focus on the discourse of authenticity to processes of authentication instead.

Towards the end of the last century, however, the sociological study of tourism moved largely away from the problématique of authenticity. The centrality of the topic declined under the impact of two historical developments: the post-modern turn in Western tourism and the rise of non-Western tourism. Radical post-modern thinkers like Baudrillard (1994) denied the existence of "originals" in the contemporary world, which allegedly thrives on simulacra, while authors like Ritzer and Liska (1997) argue that a craving for fun and enjoyment replaced the quest for authenticity as the dominant post-modern tourist motivation. "Post-tourists," according to these authors, might ironically revel in enjoying simulacra in a world supposedly devoid of originals. The rapidly expanding non-Western, particularly Asian, tourism was from the outset driven by other motives than a quest for authenticity; those motives remain a little explored topic in the study of contemporary tourism.

Another important theoretical opening was made by John Urry (1990), who introduced into tourism discourse Foucault's concept of the "gaze." Urry distinguished two principal varieties of the tourist gaze, the "romantic" and the "collective", to which he and others (e.g. Maoz, 2006 on the "mutual gaze" and Holloway, Green \& Holloway, 2011 on the "intratourist gaze") later added several more. Though Urry, unlike Foucault, was not directly concerned with the "gaze" as a means of control and surveillance, his work prompted others' attention to issues of power and authority in the tourism process (e.g Cheong \& Miller, 2000). But the prioritization of the visual sense in Urry's approach prevented it too from becoming the basis of a general paradigm for the sociological study of tourism, as scholars took increasing interest in the body and other senses, and turned from single-sense, ocularcentric, to multisensuous studies (Dann \& Nordstrand, 2009; Everett, 2009; 
Lagerkvist, 2007), while Urry himself turned from the study of tourism to that of the wider field of "mobilities."

The novel conceptual and theoretical developments in the field, beyond the discourses of authenticity and the tourist gaze, are closely related to a broader metatheoretical re-orientation in contemporary sociology and philosophy, which in turn reflects some of the wider late modern social trends discussed above. Most significant for present purposes is, first, a shift from a synchronic to a diachronic perspective, involving a change of emphasis from permanence to flux, from being to doing, from structure to agency, from sedimented social patterns to the process of their emergence, and from a focus on the more stable fixtures of social life to the mobilities linking them; and second, a post-modern tendency to stress the de-differentiation between social domains, the break-down of conventional binary concepts, the interpenetration between formerly opposite categories, and the blurring of the border between reality and virtuality. We shall here discuss three important inter-related theoretical developments sharing this perspective, the mobilities "paradigm", the performativity approach and actor-network theory (ANT).

\section{Mobilities}

The most encompassing theoretical development of the last decade is the elevation of the concept of "mobilities" into the anchor of an allegedly new paradigm, by which several heretofore distinct fields (Hannam, Sheller \& Urry, 2006; Urry, 2007) are to be integrated into a single "post-disciplinary" domain (Coles, Hall \& Duval, 2006). Though instigated by the sweeping changes in late Western "liquid modernity" (Bauman, 2000), the mobilities paradigm is not, unlike the discourse of authenticity, culture bound; its applicability to non-Western societies has, however, to be tested. The principal proponent of the new paradigm, John Urry (2000, p. 186), argued for a "novel agenda for sociology", focusing on the "diverse mobilities of peoples, objects, images, information, and wastes." He claimed that the "diverse mobilities that are materially transforming the 'social as society' into 'social as mobility' include imaginative travel, movements of images and information, virtual travel, object travel and corporeal travel" (ibid, p. 186).

In a more comprehensive conceptualization, offered in the Editorial to a new journal, Mobilities, Hannam et al. (2006, p. 1-2) argued that a "mobility turn" is transforming the social sciences, and transcending the disciplinary boundaries established in the $20^{\text {th }}$ century; they claim that an "emergent mobilities paradigm" challenges the ways in which "a-mobile" social science research has been conducted (ibid, p. 5). Tourism is seen as part of a sub-set of a vast and heterogeneous complex of global mobilities, which also includes migration, return migration, transnationalism, diasporas, and other obligatory as well as voluntary forms of travel (ibid). Society consists of boundless networks of diverse flows, interconnected by nodes, such as "stations, hotels...resorts, airports, leisure complexes, and cosmopolitan cities" (ibid, p. 12). However, the capacity of using these new mobility opportunities is unequally distributed between, and within, contemporary societies (Hannam, 2008). The mobilities model implicitly destabilizes some of the basic common-sense binary concepts on which the sociological approach to tourism has been unreflectively grounded: 
The "Tour" - The common-sense model of the "tour," based on the binary distinction between "home" and "away" (with the tour conceived as a circular trip "home-awayback home") is destabilized by contemporary communication technologies, which enable tourists to feel as "being simultaneously at 'home'...while also being 'away" (White \& White, 2007, p. 88; Paris, 2012), and further weakened by several mobilityrelated developments (Hui, 2009): One, multi-locality; as urbanites acquire second or even third homes in their own country or abroad, "home" and "away" become relative to the current place of sojourn (Haldrup, 2004; Hall \& Müller, 2004). Two, migration; with growing residential and labor mobility (Janta, Brown, Lugosi \& Ladkin, 2011), trips from the new to the old home become a widespread form of tourism, but constitute both a tour away and towards a home. Three, diasporas; as migrant national, ethnic or religious minorities establish multi-generational diasporic communities, their members' visits to their place of origin are typically trips to the (old) natal home for the older generation, but away from home for the younger one (Duval, 2003). Four, new nomadism; a small, but significant phenomenon is the growing number of Westerners, who have no fixed place of abode, but move permanently from one locality to another (e.g. S. Cohen, 2011 on "lifestyle travellers").

"Tourism" - The late modern process of de-differentiation in social life (Uriely, 2005; Edensor, 2007; Gale, 2009) weakens the conventional boundaries between distinct domains, such as work and leisure, study and entertainment, ordinary life and extraordinary holidays, and even reality and fantasy. The progressive blurring of boundaries between different mobilities provoked a de-differentiation of the domain of tourism from other mobilities, such as labor/retirement/lifestyle migration, second home visits, commuting, diaspora living, exploration, volunteering, sporting activities, events, and temporary migration. This process provoked some authors to coin the catchphrase "the end of tourism" (Gale, 2009; Jensson, 2002).

"Extraordinariness" - The contrast between the extra-ordinary ambience of touristic situations and the ordinariness of daily life, expressed in such binary terms as "everyday-holiday," was seen as homologous to the secular-sacred binary in Western religions (Graburn, 1977). According to analysts of late (or post-) modernity that distinction is getting blurred, as tourism becomes increasingly imbricated in everyday life and is no longer contained in specific locations and set aside periods (Franklin \& Crang, 2001). Consequently, tourism's aura of extraordinariness is weakened as it becomes de-exoticized (Edensor, 2007; Larsen, 2008). This, in turn, facilitates its commodification, but also reduces its special appeal. On the flip-side, ordinary life penetrates tourist travel. According to Larsen (2008, p. 21), "everyday routines and conventions inform tourist performances;" for example, "much traditional tourism revolves around socializing ... with one's co-traveling family and friends".

"Hosts and guests" - The binary "host-guest," the cornerstone social relationship of any tourist system, has also been contested (Sherlock, 2001). "Hosts" are frequently themselves "guests" in little developed destinations, wherein outsiders often engage in tourist businesses (e.g. E. Cohen, 2006). Likewise migrant workers, guests themselves within a country, often also assume the role of host through casual employment in tourist enterprises (Janta et al., 2011).

"Domestic-international" - This widely used binary in tourism statistics and research has been problematized by mobilities theorists. Writing before the 9/11 2001 events, 
Urry (2000) proposed the replacement of the modern concept of "society", based upon the metaphor of a "region," in which a boundary is drawn around clusters of objects, by a post-modern, unbounded concept of society, based on the metaphors of "networks" and "fluids." It follows that boundaries of states will become increasingly obsolete; borders will become ever more permeable and the distinction between "domestic" and "international" tourism, based as it is on a "boundary," will become progressively less important. This approach matches the notion of supraterritoriality (Scholte, 2000), which, connected to the concept of deterritorialization in globalization studies, considers mobility a force for cosmopolitanism, a theme that has driven studies of cosmopolitanism in tourism (e.g. Germann Molz, 2006).

However, the trend predicted by Urry has been countervailed in the first decade of the $21^{\text {st }}$ century by increased securitization, provoked by the intensified fear of international terrorism throughout the globe after 9/11, and the strengthening of anti-immigrant sentiments in many Western countries. Consequently, "state borders...have become repoliticized" and "the securitization of international borders became more acute," as "states...deepened enforcement measures at their international boundary lines" (Cunningham, 2007, p. 143). Though within some virtually borderless mega-regions, such as that of the Schengen states in Europe, the flow of travelers across national borders is virtually unimpeded, those regions themselves are bounded entities. Thus, the Schengen mega-region has imposed increasingly stricter entry regulations on potential tourists from outside it, and intensified border controls, in order to prevent illegal immigration and to protect the security of its member states (Bosworth, 2008). Here again we are reminded that mobility is neither seamless nor equitably distributed across societies (Gogia, 2006), but intertwined with power differentials.

\section{Performativity}

"Performativity" is an innovative approach of crucial significance in the re-orientation of contemporary sociology. This approach has been deployed in the tourism literature in two principal modes, a moderate and a more radical one. The moderate mode draws its inspiration from Erving Goffman's $(1959 ;$ 1974) performance approach to social interaction: behavioral acts are strategically deployed as means of self-representation and impression management in everyday life. People are always metaphorically on stage, performing in front of a public through social interactions. The early performance theorists in tourism studies, such as Bruner (2005b) and KirschenblattGimblett (1998) focused primarily on the stage in a more literal sense, particularly on tourist attractions and cultural performances and events. More recent work in this mode deflected the focus to the attending public, analyzing tourists' behavior as diversely habituated performances (Edensor, 2001; 2007).

The mode of radical performativity goes a step beyond Goffman. Departing from the concept of "performative speech acts" of the philosopher of language John L. Austin (1978), it expands the concept of performativity beyond utterances to include non-lingual symbolic acts, such as gestures, salutations or prostrations. The mode focuses on how performative acts "do things" to constitute a reality-inbecoming, rather than reflect a social structure. The approach thus denies an independent standing to social entities, including tourist settings, such as destinations, 
attractions or events, but sees them as dynamic products of the performative acts of the public. The performativity perspective similarly denies the existence of a stable personal identity and stresses that individuals have the power to perform multiple and shifting selves (Bell, 2008).

Hannam et al. (2006, p. 13) thus make the important observation that the notion of places, which have "frequently been seen as pushing or pulling people to visit...needs to be problematized". They contend that "the emergent mobilities paradigm ... argues against the ontology of distinct "places" or "people". Rather there is a complex relationality between places and persons connected through both performances and performativities" (ibid, p. 13). Hence, places are "not so much fixed but are implicated within complex networks by which 'hosts, guests, buildings, objects and machines' are continually brought together to perform certain performances..." (ibid, p. 13). This perspective is reinforced by recent novel thinking in geography. Anderson (forthcoming), for example, proposes to look at "place" relationally, not just as a simple connection of parts, but as a "convergence" or merger of constituent parts that blur together for a moment in time.

Tourist destinations and attractions are thus seen as nodes of reiterated performative acts (e.g. sanctifying a locality, admiring a site, commemorating an event); they are nothing but sedimentary accumulations of such acts. But performativities do not only (re)produce social entities, they can also critically counter hegemonically imposed public sites or attractions, especially through acts of resistance (e.g. Obrador Pons \& Carter, 2010). The implications of the performativity perspective for conventional conceptions of "destinations" and "attractions," and for the study of tourist images, are far-reaching, but have not yet been worked out sufficiently in contemporary tourism studies.

\section{Actor-network theory}

Both mobilities and performativity theorists perceive society only as an ongoing process - as if it can be analyzed, in medical analogy, solely in terms of "physiology," but not of "anatomy," or, in linguistic analogy, only as "speech," but not as "language". ANT further radicalizes this perspective. Its principal protagonist, Bruno Latour (2005), criticizes the Durkheimian assumption in sociology of the existence of some independent, stable "social" domain of reality, with explanatory power. $\mathrm{He}$ denies the existence of such a separate domain, and argues that its proponents "have confused what they should explain with the explanation" (ibid, p. 8). Latour argues that, in the complex contemporary world, the processes by which the "social" is actually produced should become the principal task of sociological inquiry. In his view, the "social" is not the glue which holds society together; rather "it is what is glued together by many other types of connectors" (ibid, p. 5; emphasis in original). It is not a "specific realm...but only... a very peculiar movement of re-association and reassembling...a trail of associations between heterogeneous elements" (ibid, p. 5). The "social" becomes "visible only by the traces it leaves... when a new association is being produced between elements which themselves are by no means 'social"' (ibid, p. 5; emphasis in original). Latour's "sociology of associations thus reverses...the [conventional] sociology of the social" (ibid, p. 12). 
These processes of association and reassembling are at the heart of ANT. The approach postulates that:

"collective action is... a concatenation of actors and non-human entities, and a translation [that] implemented through a translator, will create heterogeneous associations between these different actors, which then become networked. The translation is a series of successive movements, transformations, redefinitions of the collective project...in which actors are mobilized in various ways. The network is... a chain of actions consolidated by mediators... [in which] actors and non-humans are associated with the same project" (Paget, Dimanche \& Mounet, 2010, p. 829-30).

Four important points should be noted in this definition: One, networks are always assembled and re-assembled for particular projects; they are constantly in flux. Two, networks are impermanent entities, their existence depending on continuous performance of relations. Three, in contrast to other network approaches, ANT ascribes agency to non-human entities in the network, such as objects, technologies, machines, implements, computers, etc. (Ren, 2011). Actor-networks are thus hybrid, heterogeneous configurations of material and semantic relations. Four, translators, in contrast to mediators, are the active component of networks, effecting the changes, which lead toward the realization of the project.

This innovative approach opens up new conceptual and methodological perspectives for tourist studies (Jóhannesson, 2005), but has as yet been rarely, and mostly only recently, introduced into tourism research (Valkonen, 2010; van der Duim, 2007; van der Duim, Ren, \& Jóhannesson, 2012). Paget et al. (2010) have used ANT in a study of a successful innovative project in a French ski resort; Ren (2011, p. 858) sought to demonstrate, by the use of ANT, how "a rather unlikely [non-human] destination actor, the [polish] oscypek cheese, is enacted in different versions as it engages with tourism, tradition, craftsmanship, hygiene and legislation;" Gren and Huijbens (2012) deployed it in their paper intended to re-introduce the Earth into tourism theory; Rodger, Moore and Newsome (2009) used it to examine the sciencewildlife tourism interface, and John Tribe (2010) used it to analyze the International Academy for the Study of Tourism (IAST).

These three novel theoretical approaches, mobilities, performativity and ANT, which are in many respects mutually supportive, open fresh and unconventional vistas for tourism research. But they also suffer from serious limitations and ambiguities, which might impair their applicability to tourism: One, none of these theories is a fully-fledged "paradigm". Instead, they represent new perspectives, which foreground aspects of society that have been allegedly neglected by earlier theories. However, none offer a set of basic (predictive) propositions, which could be evaluated in empirical research. Two, the scope of the paradigmatic claims of these theories is vague: are they meant to be of universal significance, or limited specifically to contemporary (Western) "liquid modernity" (Bauman, 2000)? This is a crucial question for tourism research, which increasingly shifts its focus to the phenomenal expansion of (inbound and outbound) travel in the non-Western world. Three, by stressing their innovative insights, these theories disregard some significant constraints to their applicability, e.g. the increasing significance of securitization as a limitation to mobilities, the role of "sedentization" in performativity theory, and the 
unacknowledged implicit "social" character of such concepts as "association" and "actor" (which implies "action") in ANT.

Owing probably to their radical re-orientation of perspectives, their relatively new import into the context of tourism, and in the case of mobilities, the potential to create unease amongst students of tourism about the discrete identity of the field of tourism, the three theories have as yet found few followers in contemporary tourism studies. A partial hiatus thus exists between innovative theory and rather conventional approaches in empirical research, as the following section helps show.

\section{Current Issues in the Study of Tourism}

We now turn our discussion to several current issues in the relationship between tourism and broader social, environmental, cultural and political processes of change in the contemporary world. Our selection of these issues is based upon our own evaluation of, and familiarity with, what constitutes important areas for problemoriented work at the interface of contemporary society and tourism and our recent review of sociologically-related literature in tourism studies.

Social justice - There is a growing concern in tourism studies with issues of social justice. An increasing number of researchers are engaging in advocacy-oriented research. They seek to move knowledge production in tourism away from neo-liberal market ideologies (Higgins-Desbiolles, 2006; Pritchard, Morgan \& Ateljevic, 2011). The primary theoretical orientation of this growing body of work is critical theory (Nash, 2007), which seeks to politicize research, and transform society to a more equitable state, through inquiry in which moral and ethical obligations are intrinsic (Pritchard et al., 2011). The field of tourism should be pushed towards a political agenda that "promote[s] social justice and equality through tourism across the world" (Ateljevic, Hollinshead \& Ali, 2009, p. 549). In his actor-network analysis of IAST, Tribe (2010) outlines the relatively recent introduction of critical theory to tourism, which has manifested in a developing critical tourism network. This network is largely premised upon bringing social justice in and through tourism, an aim that has also underpinned the development of a transformative 'hopeful tourism' perspective (see Pritchard et al., 2011), which argues that "[i]n our contemporary moment, the sole pursuit of instrumental tourism knowledge becomes less justifiable" and that "hopeful tourism offers the academy an opportunity to participate in the creation of a more just and sustainable world" (ibid, p. 957).

Hopeful tourism suggests a values-led research agenda that includes reaching towards greater social justice and emancipation for "under-served life worlds", identifying such topics as disability, older people, and social class as foci of future tourism enquiry. Indeed, there is increasing evidence that tourism studies are serving, or have in some cases, already served, some of these topics: Yau, McKercher and Packer (2004) explored the experiences of tourists with mobility or visual impairments; Eichhorn, Miller, Michopoulou and Buhalis (2008) investigated the capacity of informational schemes to fulfill the requirements of tourists with a wider range of disabilities; furthering an agenda of social inclusion, Sedgley, Pritchard and Morgan (2011) focused on tourism experiences in later life; and Small and Harris (2012) sought social justice and emancipation for tourists who are overweight/obese in their examination of divergent airline passenger experiences. 
A further topic listed on the hopeful tourism agenda (Pritchard et al., 2011) is poverty reduction. Tourism development typically benefits the middles classes, as opposed to the poor, with the latter most affected by the negative impacts of tourism. This issue is central to the "pro-poor tourism" approach, which seeks to mitigate those impacts. Pro-poor tourism has been the subject of several studies (Hall, 2007; Chok, Macbeth \& Warren, 2007; see also the exchange between Harrison, 2008 and Goodwin, 2008) concerned with net benefits for the poor in tourism development. Harrison (2008, p.865) inserted pro-poor tourism into the context of wider development debates, and argued that advocates of pro-poor tourism work within the context of international capitalism and hence their endeavors are likely to 'bring little benefit to the poorest members of communities'.

The goal of social justice also influenced research on "social tourism," which largely focuses on economically weak groups. This can be viewed as a contemporary proxy for the study of issues of social class, a topic largely overlooked in recent tourism scholarship (Casey, 2010). Another topic of concern to social tourism is whether tourism should be a luxury or a human right (McCabe, 2009; Minnaert, Maitland \& Miller, 2009; 2011), an ethical issue in which proponents of social tourism seek a more equitable distribution of tourism experiences across all sections of society. Minnaert et al. (2011) suggest that social tourism research is still at an early stage and not yet sufficiently critiqued and nuanced. In projecting the future development of that sub-field, they point to the 'scientification' that sustainable tourism has experienced: while environmental sustainability in tourism has enjoyed legitimization as a field of inquiry for some time, it remains to be seen whether social justice will attract a critical mass of advocacy-orientated scholars.

Environmental sustainability - Research on environmentally sustainable tourism is theoretically oriented to the programmatic goals of environmentalism, with the notion of sustainability in tourism conveyed from the wider discourse of sustainable development (Saarinen, 2006). Inquiry into the environmental impacts of tourism challenges the neoliberal economic growth model of tourism (Bramwell \& Lane, 1993). Research on sustainable tourism is largely underpinned by ethical considerations of the society-environment nexus (Holden, 2009) and hence can be seen as part and parcel of the politics of ethical consumption (Butcher, 2008), albeit often cloaked with the "myth of objectivity that is part of the positivistic scientific paradigm" (Macbeth, 2005, p. 963).

The discourse of the interface of tourism and the natural environment was initially aimed at mass tourism, which was charged with subordinating environmental issues to economic interests (Kousis, 2000). In critiquing mass tourism, Poon (1993) delineated a shift towards alternative forms of environmentally concerned "new tourism". Emblematic of this turn was the rise of ecotourism, which, as a past flagship for sustainable tourism, weathered several severe critiques; it was blasted as "egotourism" (Wheeller, 1993) and maligned as exemplary of replacing collective political action with individual "politicized" consumption (Butcher, 2008).

Holden (2009, p.374) notes that despite more than twenty years of advocacy work for the sustainable development of tourism, the extent to which tourism's relationship with the natural environment has actually "improved" is both "debatable and contentious". However, despite such concerns, social research on the environmental sustainability of tourism is plentiful and ongoing, covering such topics 
as the consequences of tourism for human-environmental relations (Gössling, 2002), linkages between biodiversity, tourism and the potential for more sustainable livelihoods (Nyaupane \& Poudel, 2011) and the challenge of the tragedy of the commons in managing "common pool" tourism resources (Briassoulis, 2002; Healy, 2006). The challenge of managing common pool resources is perhaps at its trickiest, and most abstract, in the case of the tourism's relationship to global climate change. Of particular concern is the impact of the transport systems, upon which much tourism depends, on the climate. This problem emerged as an important issue in the recent discourse of sustainable tourism (Weaver, 2011). It is now widely acknowledged that the air travel industry is deeply implicated in climate change and will require effective mitigation, adaptation and governance strategies if it hopes to move on to a sustainable emissions path.

Social research on tourism and climate change spans a range of specific issues, from destination-level - such as how tourism promoters are adapting landscape representational strategies to biophysical changes in light of climate change (Buzinde, Manuel-Navarrete, Kerstetter and Redclift, 2010) - to the broader level of air travel's contribution to climate change. The latter has been addressed in studies on the changing social norms regarding excessive tourist air travel, or "binge flying" (S. Cohen, Higham \& Cavaliere, 2011), on the role of frequent flyer programs in encouraging highly mobile lifestyles (Gössling \& Nilsson, 2010) and on "slow travel" alternatives to flying (e.g. Dickinson, Lumsdon \& Robbins, 2011).

Much of the research on tourism and climate change has turned to tourism consumer behavior (e.g. Gössling, Scott, Hall, Ceron \& Dubois, 2012), reflecting the understanding that public behavior change is needed if the tourism system is to shift to a sustainable emissions path (Miller, Rathouse, Scarles, Holmes \& Tribe, 2010). Weaver (2011) warns, however, that endeavours to move tourism transport towards carbon neutrality should not lead to a disregard of a more localized sustainability agenda; hence reducing emissions must be considered in the context of other destination-level issues, such as local air pollution problems, equitable water usage (e.g. Cole, 2012), habitat restoration and biodiversity preservation, as well as with other quality of life initiatives.

Natural Disasters - have often been seen as "acts of God" in the past, beyond human control or influence. As a corollary of this view, the study of disasters was until recently an isolated specialty, unrelated to wider theoretical developments in mainstream sociology (Tierney, 2007), and concerned mainly with issues regarding responses to disaster (Drabek, 1986), and especially the management of its consequences. It was in anthropology, particularly through the work of Hoffman and Oliver-Smith (1999) and Oliver-Smith and Hoffman (2002a), that natural disasters came to be understood as "happenings humans themselves to some degree construct" and that many "socio-cultural elements [are] entangled within the vortex of [natural] catastrophe" (Hoffman \& Oliver-Smith, 1999, p. 2). The main insight from these researchers is that whilst disasters are exogenic to society, the intensity and breadth of their impact might result from or be aggravated by "a historically produced pattern of 'vulnerability,' evidenced in the location, infrastructure, sociopolitical organization, production and distribution systems and ideology of a society" (Oliver-Smith \& Hoffman, 2002b, p. 3). 
Though tourism disasters have not been systematically studied from that perspective, it is evident that tourism areas, especially those which underwent rapid development, are particularly vulnerable to natural disasters; their location, e.g. on beaches or mountain slopes, their impact on basic environmental features, the absence of precautions or emergency procedures, and the often prevailing ludic atmosphere, exposes them to sudden, unexpected natural threats, which developers as well as their clients usually disregard or are unaware of. Such neglected vulnerability was tragically exposed in the high price in lives and destruction that coastal tourist areas in the Indian Ocean region paid in the 2004 tsunami (Calgaro \& Lloyd, 2008; E. Cohen 2008a, p. 23-51).

In the tourism literature, disasters were generally dealt with within the wider theoretical framework of "tourism crises" (e.g. Laws \& Prideaux, 2005). Specific studies of the interface of tourism and disaster have been primarily concerned with issues of disaster management (Huan, Beaman \& Shelby, 2004; Hystad \& Keller, 2008; Ritchie, 2004; 2009). Remarkably little work has been done on the specific social processes by which the vulnerability of tourist destinations is produced, or on the conduct of tourists, hosting establishments, locals and official institutions at the outset, during and in the immediate aftermath of a natural disaster (for an exception see E. Cohen 2009). There are some studies, however, on the decline and revival of tourism in wake of a disaster (e.g. E. Cohen, 2008b; Henderson, 2005; Ichinosawa, 2006; Rittichainuwat, 2011) and of the remarkable phenomenon of disaster tourism (Pezzullo, 2009; Rittichainuwat, 2008), which links this topic with the broader study of "dark tourism."

Terrorism - The intersections of terrorism and tourism, like natural disasters, have been primarily dealt with within a theoretical framework of tourism crisis management, but also within a wider discourse of political instability (Sönmez, 1998). Most studies are concerned with the vulnerability of the tourism industry to terrorism and concentrate on the response to a terrorist attack, and the means to cope with the disruption in tourist flows in its wake. For example, Blake and Sinclair (2003) examine how policymakers responded to the declining demand for tourism following the September 11, 2001 attacks in the U.S.; Cavlek (2002) analyzes how tour operators can convince tourists to visit terrorism-hit destinations; Arana and Leon (2008) focus on tourist preferences for alternative ones; and Bhattarai, Conway and Shrestha (2005) explore the degradation of Nepal's destination image under the impact of coinciding global and localized Maoist "terrorist acts."

Less explored are the social processes by which terrorist attacks on tourism sites are produced, and how seemingly arbitrary attacks could be traced to social factors. Sönmez's (1998) review of tourism and terrorism identifies the motives of terrorists in targeting tourists, and how terrorism's impact on the tourism system could consequently be used as a political tool, as key research themes. Ness (2005, p. 119) highlights the capacity for attacks on tourism locations to "inspire terror," as tourist destinations "cannot fight back." She makes the point that "the violence serves to endow its human victims with a heightened innocence, the victim's involvement being a matter of chance to some extent and their death or injury, therefore, all the more gratuitous." Ness (ibid, p. 120) attributes some cases of such locational violence to a darker side of tourism, in which, rather than being idyllic sites of leisure, "places that have been refashioned or relandscaped for touristic purpose" can engender 
feelings of cultural disemplacement amongst residents, who may experience rage and a sense of place loss that moves them to violence.

Another area of interest at the nexus of tourism and terrorism is the willingness of tourism providers and governments to manipulate the definition of "terrorism" in order to protect the tourism industry. Ness (2005) examines contested interpretations of touristic violence, detailing how an intended act of "terrorism" at the Pearl Farm Beach Resort in the Philippines in 2001 was rebranded and marketed in the media as 'banditry' in order to protect the destination's image, without evidence that the perpetrators sought to steal anything. A more recent incident in Thailand, however, illustrates the limits of the malleability of concepts before a social backlash results. The Thai government attempted to save foreign tourism from the impact of the 2012 bombings in Bangkok by denying the acts can be classified as "terrorism" (defined narrowly as intended mass destruction), as the bombs were meant to assassinate (foreign) individuals, rather than kill a large group of (local) people. This manipulation of the definition of 'terrorism' for political purposes was met by derision in the press, who openly criticized the downplaying of the events (The Nation, 2012).

Heritage tourism - a sub-category of cultural tourism - is an increasingly popular tourist activity, which has provoked considerable discussion in the literature (e.g. Harvey, 2001; Jamal \& Kim, 2005; Lowenthal, 2005; Nuryanti, 1996; Timothy \& Boyd, 2006) and numerous studies of particular heritage sites, such as Bruner (2005a) on New Salem, Illinois and Elmina Castle, Ghana, Collins-Kreiner and Gatrell (2006) on Haifa's Bahá'i Gardens, Daher (2005) on Salt, Jordan, Edensor (1998) on the Taj Mahal, Poria, Reichel and Biran (2006) on the Anne Frank House in Amsterdam, and a volume on Southeast Asian heritage studies (Hitchcock, King \& Parnwell, 2010).

"Heritage" is a moot concept (Edson, 2004), with fuzzy semantic boundaries. Formal definitions of "heritage" by international organizations differ (Ahmad, 2006). It has been previously primarily restricted to the tangible legacies of human archeological, historical and cultural past, but its definition has recently been expanded to include, on the one hand, valued natural sites, and, on the other, intangible cultural treasures (Ahmad, 2006; Vecco, 2010). Rather than separate domains, the natural and cultural heritages commingle, since, "no aspect of nature is unimpacted by human agency, no artifact devoid on environmental impress" (Lowenthal, 2005, p. 81). What constitutes "heritage," however, is not a neutral, objective issue; instead, any "heritage" is socially produced and historically contingent (Harvey, 2001).

Heritage tourism has often been seen as an expression of romantic nostalgia for an inexorably lost past (Caton \& Santos, 2007; McMorran, 2008); but studies have pointed to the significance of heritage sites as markers of continuity in a fluctuating world, as symbolic of distinctiveness under conditions of cultural globalization and homogenization (Logan, 2001), and as icons of personal or cultural identity (Breathnach, 2006; Edson, 2004).

With the growing popularity of heritage tourism, governments, communities and individual entrepreneurs exploited heritage sites for economic purposes (McMorran, 2008). A "heritage industry" (Edson, 2004, p. 343) emerged, engendering a "conflict... between heritage protection and tourism development" $(\mathrm{Li}$, 
Wu \& Cai (2008, p. 308). The conflict is particularly pronounced in developing countries, where heritage tourism is rapidly expanding. Many heritage sites are threatened by increasing commercialization (Edson, 2004; Timothy \& Prideaux, 2004), or damage from uncontrolled tourist access, but also from excessive restoration, intended to increase their touristic attractiveness.

While conservation, preservation and restoration of heritage sites are allegedly based on sound scientific principles, these processes are in fact profoundly suffused by ideological and political considerations, as national and other authorities exploit them to strengthen the identity of their collectives or their own legitimation. Such considerations influence decisions regarding the choice of sites destined for preservation and the manner of their restoration. However, the hegemonic formation, interpretation and representation of heritage sites by the authorities often provoke resistance and contestation. Waterton (2009, p. 37; emphasis in original) argues that the heritage policy of the New Labour in the UK, ideologically "reaffirms and legitimizes the cultural symbols of an elite social group as a consensual representation of national heritage". Likewise, Waitt (2000, p. 835) pointed out, in a study of a heritage site in Australia, that the "commodified version of history" presented at the site "based upon the rhetoric of Australian nationalism has silenced alternative versions of the past which highlight oppression, racism and conflict." Frost (2004, p. 281) also contests the Eurocentric view of Australian history in heritage interpretation in his case study of Pearl Luggers, by foregrounding suppressed themes such as "the treatment of Aborigines and the restriction of Asian immigration". Sub-collectives within nation states often seek recognition of their disregarded heritages (Bandyopadhyay, Morais \& Chick, 2008; Porter \& Salazar, 2005).

Though most heritage sites are primarily national treasures, in the post-Second World War period the idea was promoted that some sites of outstanding cultural or natural importance to the common heritage of humanity should be preserved on the global level. In 1972, UNESCO instituted procedures for the designation of World Heritage Sites (WHSs), but the modernist criteria, such as presumed universal values and international standards of practice, deployed by UNESCO in WHS designations, were in the 1990s challenged by post-modernist relativism, involving claims that such criteria were "essentially Eurocentric" and "driving towards [global] uniformity" as well as clashing with the belief systems and behavioral mores prevalent in local communities (Logan, 2011, p. 54). Logan (ibid, p. 55) claims that the post-modernist critique had increased the strength of the periphery to articulate resistance to UNESCO's global heritage approach, and reinforced "efforts to protect traditional popular arts and crafts and vernacular buildings alongside the 'high' forms [dominating] official conservation efforts".

Recent studies, however, indicate another emergent tension between national and universal claims to WHSs. Chambers and Rakic (2008, p. 145) point out the paradox that heritage sites considered to be of outstanding universal value (and hence awarded the World Heritage accolade), are therefore implicitly "no longer expected to be perceived as symbols of particular national identities." WHS designations might thus provoke debates on issues of ownership and belonging and turn such sites into contested heritage.

An emergent issue is the place of local populations in protected sites. The prevailing tendency has been to keep locals out of "museumized" archeological sites, 
or turn historical urban quarters into "living museums." The issue is particularly acute in bigger WHSs, which may cover several square kilometers. In such areas "local ways of life tend to be subordinated to concerns about conservation and tourism development" (Miura, 2010, p. 104). Miura (ibid) notes that in the case of one of the most extensive WHSs, Angkor in Cambodia, there was a shift in policy from preserving the site as a "frozen idealized past," from which local traditional activities have been banned, to turn it instead into a "living" site, of which the local people would constitute an integral part. In practice, however, the locals were marginalized and restricted in their movements and access to resources (ibid, pp. 106-7). Still, with the recent adoption of a community-based approach, a more inclusive and sustainable policy of heritage site management has emerged in Angkor (ibid, p. 126-7). Nonetheless, a recent study of six WHSs (Landorf, 2009) shows that despite policy changes, the planning process of these sites still lacked a holistic approach and genuine engagement with local communities.

Embodiment and affect - Drawing on theoretical insights from feminist and critical social theory, there is a growing wave of sociological research that attempts to overcome understandings of tourism "built on Western hierarchical dualisms" that tend "to produce hegemonic, disembodied, and masculinist knowledge" (Johnston, 2001, p.181). Veijola and Jokinen (1994) observe that the body has been mostly absent in tourism studies, mirroring its broader omission in structuralism. In contrast, Thrift (1997) argues for an appreciation of performative presentations in everyday life through the medium of the body, including its senses. Thrift observes that the body has been marginalized through its representation as text. One of the dangers of this is "decorporealizing the figure of the woman", in which "the distinction between the bodies of men and women are minimized" (ibid, p. 137) and then converted into universalist accounts. Johnston (2001) examines this issue not only in terms of gendered accounts, but also for sexed and sexualized bodies.

Thrift (1997) sees embodiment as an expressive ongoing relation with the world, which bridges any attempt at a dualistic divide between subject and object, by folding the two into each other. Obrador Pons (2003) further critiques a Cartesian division between subjects and objects and argues that an embodied perspective of tourism is necessary in order to apprehend the everyday ordinary practices of tourists, rather than focusing on the exotic and extraordinary, such as sightseeing. He (ibid, p.57) thus argues that [tourism] experience should be understood through "multiple corporeal and sensual practices", not just sight and discourse. An appreciation of the body and its senses thus critiques Urry's (1990) notion of the tourist gaze (see Veijola \& Jokinen, 1994). Although sight is one way in which the body participates in tourism, Obrador Pons (2003, p.57) argues that Urry privileges the visual through its sole focus on landscape; Urry's "gaze" is said to be "based on a masculine, middle class and imperialistic imaginary made dangerously universal."

Past critique of the dominance of the visual in tourism studies is countered by a rise in scholarship examining other visceral aspects of embodiment, such as the vocal and listening within the context of music festivals (Waitt \& Duffy, 2010), the tactile or haptic (sense of touch) within the sensuality of sunbathing and building sandcastles (Obrador Pons, 2009) or the role of smell in tourists' experiences of charter resorts (Andrews, 2005). Others explore the role of the body in tourism by focusing on sleeping practices (Valtonen \& Veijola, 2011) or on the multisensory experiences of food tourism (Everett, 2009). Attention to the role of other senses in 
experiencing tourism, beyond the visual, does not, however, underplay the continued importance of visuals in eliciting enhanced understandings of multisensual embodied experiences (see Scarles, 2010). There is, nonetheless, substantial room for further studies of how sensory experiences are mobilized in and through tourism. And as Scarles (2010) signals, these types of studies offer fresh routes to accessing another under-researched area within tourism studies, that of affectual encounters.

Affect, often associated with emotion and feeling, is another neglected tourism research area, due to prevailing Cartesianism and the privileging of disembodied accounts; affect is also difficult to capture in print (Thrift, 2004). Three notable exceptions are Conran (2011), who studied intimacy as an embodied emotion in volunteer tourism experiences, Modlin, Alderman and Gentry (2011), who examine affective dimensions in guided tours of plantation house museums in the Southern U.S., and Rakic and Chambers (2012), who discuss affective aspects of embodiment in place consumption. Tung and Ritchie (2011) point to the importance of understanding tourists' emotions during an experience, whether they be positive ones, or as E. Cohen (2011) observes in an analysis of tourist cartoons, rather distressing affective reactions, such as fright, frustration, confusion or perplexity. Whilst other studies of emotion in tourism have been offered from a consumer behavioral (e.g. Bigné \& Andreu, 2004), and more recently, an affective neuroscience perspective (Pearce, 2012), further sociological accounts of affect and emotions in tourism are needed.

Mediatization - is a process by which contemporary society is being "permeated by the media to an extent that [they] may no longer be conceived of as being separate from cultural and other social institutions" (Hjarvard, 2008, p. 105). The term was introduced into tourism studies mainly by Scandinavian communication researchers, who studied the interface between tourism and the media (Jensen \& Waade, 2009; Knudsen \& Waade, 2010; Lagerkvist, 2008). The study of mediatization focused on three principal topics:

One, the mediatization of the tourist experience (Jansson, 2002; Tussyadiah \& Fesenmaier, 2009). Mediatization envelops tourism attractions in a thick mantle of images and representations. Contemporary tourists are typically already saturated by media images of an attraction prior to approaching it, and thus virtually precluded from unmitigated access to, and experience of them. This has significant consequences for the meaning of "authenticity" in mediatized touristic situations. While modern researchers would tend to consider mediatization as impairing the possibility of experiences of objective authenticity, those with a post-modern inclination see in it the potential of a new kind of authenticity. Thus Ooi and Stöber (2010, p. 79) argue with respect to place branding: "[i]nstead of seeing place branding as a source of authentic corruption, the place branding is part of the emergent authenticity." The attraction and its mediated image become seamlessly united, or, as Månsson (2010, p. 169) put it: "the tourist gaze becomes intertwined with the general consumption of media images as tourists consume mediated images of places."

Two, the interplay between simulations and real experiences (Jansson, 2002; Jensen, 2010). The issue of principal interest here is the blurring of the boundary between physical and imaginary places (Jensen \& Waade, 2008). Jensen (2010, p. 215) observed that at present "[m]edia not only reproduce reality...they produce events of their own," and claims that "it is becoming increasingly difficult to 
distinguish between actual and mediated experiences." However, even though some simulations might come eerily close to reality, Jansson (2002, p. 429) argues that "people [still] uphold the distinction between simulations and "real experiences"". Månsson (2010, p. 179-180) similarly contends that "mediatized tourism [i.e. images of places in the media] will not replace physical traveling - on the contrary it triggers an interest in first-hand experiences."

Three, the role of tourist agency in creating media images. Månsson (2011, p. 1635) claims that in the literature of media representations of tourist spaces, the tourist is assumed to be a "passive media consumer who is seen only as a user of media products". Her study of social media networks, however, leads to the theoretically significant conclusion that tourists have agency in the mediatized representation of tourist sites; this finding destabilizes the dichotomy of media producers/consumers and qualifies Jenkins" (2003) notion of the "circle of representation" by which tourist images are perpetuated.

\section{CONCLUSIONS}

In this article we reviewed the broad social trends and specific historical events that have affected both the nature of contemporary tourism and sociological approaches to its study. We showed how the focus of sociological inquiry in tourism shifted from the earlier discourses of authenticity and the tourist gaze, respectively, to three key innovative theoretical approaches, mobilities, performativity and ANT, which reflect a broader meta-theoretical re-orientation in contemporary sociology and philosophy. Although these novel approaches offer fresh horizons for tourism studies, their deployment in tourism research has to date been limited. We attributed this partial hiatus between innovative approaches and their application to key research issues to the radical re-orientation implicit in these perspectives, their relatively new import to tourism studies, and in the case of the mobilities approach, its potential to create unease amongst students of tourism as to the discrete identity of tourism as a field of study.

We identified several current research issues, which we suggest represent important areas for problem-oriented work at the intersections of tourism and contemporary society: social justice, environmental sustainability, natural disasters, terrorism, heritage, embodiment and affect, and mediatization. Our survey of current issues, however, was not exhaustive; there are further important issues not dealt with here that are under-explored and under-theorized in the contemporary sociological study of tourism, such as medical, urban, spiritual, space, volunteer and dark tourism, and tourism's relationship to global financial crises, social media, crime, and prostitution.

One highly important issue that we have only touched upon here, and that has received limited attention elsewhere, which we intend to treat separately in another paper due to its ground-breaking nature, is the applicability of current sociological theories to non-Western tourism. The rapid rise in non-Western tourism, especially from Asia, has left tourism studies conceptually ill-equipped as most of its theories have been generated from Western contexts (Winter, 2009), and are thus culturally contingent. The repercussions of this are not only that past concepts, such as that of 
authenticity, may have limited applicability to non-Western tourists, but also that more recent theoretical developments, such as those offered by mobilities, performativity and ANT, need exploration in non-Western contexts before they can begin to claim universal significance.

Acknowledgements - We would like to thank Avital Biran (Ben-Gurion University of the Negev) and Victoria Eichhorn (University of Surrey) for their insights and comments on earlier drafts of this article.

\section{REFERENCES}

Ahmad, Y. (2006). The scope and definitions of heritage: From tangible to intangible. International Journal of Heritage Studies 12(3), 292-300.

Anderson, J. (forthcoming). Relational places: The surfed wave as assemblage and convergence. Environment and Planning D: Society \& Space.

Andrews, H. (2005). Feeling at home: Embodying Britishness in a Spanish charter tourist resort. Tourist Studies, 5(3), 247-266.

Arana, J.E. \& Leon, C.J. (2008). The impact of terrorism on tourism demand. Annals of Tourism Research, 35(2), 299-315.

Ateljevic, I., Hollinshead, K. \& Ali, N. (2009). Special issue endnote: Tourism and worldmaking - where do we go from here? Tourism Geographies, 11(4), 546-552.

Austin, J.L. (1978). How to do things with words, 2nd edition. Oxford: Oxford University Press.

Bandyopadhyay, R., Morais, D.B. \& Chick, G. (2008). Religion and identity in India's heritage tourism. Annals of Tourism Research, 35(3), 790-808.

Bauman, Z. (2000). Liquid Modernity. Cambridge: Polity.

Baudrillard, J. (1994) Simulacra and Simulation. Ann Arbor: University of Michigan Press.

Beck, U. (1992). Risk Society: Towards a New Modernity. London: Sage.

Bell, E. (2008). Theories of Performance. Los Angeles: Sage.

Bhattarai, K., Conway, D. \& Shrestha, N. (2005). Tourism, terrorism and turmoil in Nepal. Annals of Tourism Research, 32(3), 669-688.

Bigné, J.E. \& Andreu, L. (2004). Emotions in segmentation: An empirical study. Annals of Tourism Research, 31(3), 682-696.

Blake, A. \& Sinclair, M.T. (2003). Tourism crisis management: US Response to September 11. Annals of Tourism Research, 30(4), 813-832.

Bosworth, M. (2008). Border control and the limits of the sovereign state. Social and Legal Studies, 17(2), 199-215. 
Bramwell, B. \& Lane, B. (1993). Sustainable tourism: An evolving global approach. Journal of Sustainable Tourism, 1(1), 1-5.

Breathnach, T. (2006). Looking for the real me: locating the self in heritage tourism. Journal of Heritage Tourism, 1(2), 100-120.

Briassoulis, H. (2002). Sustainable tourism and the question of the commons. Annals of Tourism Research, 29(4), 1065-1085.

Bruner, E. (2005a). Abraham Lincoln as authentic reproduction. In E. Bruner, Culture on tour (pp. 145-168). Chicago: University of Chicago Press.

Bruner, E. (2005b). Culture on tour. Chicago: University of Chicago Press.

Butcher, J. (2008). Ecotourism as life politics. Journal of Sustainable Tourism, 16(3), 315-326.

Buzinde, C.N., Manuel-Navarette, D., Kerstetter, D. \& Redclift, M. (2010). Representations and adaptation to climate change. Annals of Tourism Research, 37(3), 581-603.

Calgaro, E. \& Lloyd, K. (2008). Sun, sea, sand and tsunami: Examining disaster vulnerability in the tourism community of KhaoLak, Thailand. Singapore Journal of Tropical Geography, 29(3), 288-306.

Cary, S.H. (2004). The tourist moment. Annals of Tourism Research, 31(1), 61-77.

Casey, M.E. (2010). Low cost air travel: Welcome aboard? Tourist Studies, 10(2), $175-191$

Caton, K. \& Santos, C.A. (2007). Heritage tourism on Route 66: Deconstructing nostalgia. Journal of Travel Research. 45(4), 371-386.

Cavlek, N. (2002). Tour operators and destination safety. Annals of Tourism Research, 29(2), 478-496.

Chambers, D. \& Rakic, T. (2008). World heritage: Exploring the tension between the national and the "universal." Journal of Heritage Tourism, 2(3),145-155.

Cheong, S. \& Miller, M.L. (2000). Power and tourism: A Foucauldian observation. Annals of Tourism Research, 27(2), 371-390.

Chok, S., Macbeth, J. \& Warren, C. (2007). Tourism as a tool for poverty alleviation: A critical analysis of 'pro-poor tourism' and implications for sustainability. Current Issues in Tourism, 10(2-3), 144-165.

Cohen, E. (1979). A phenomenonology of tourism experiences. Sociology, 13(2), 179201.

Cohen, E. (1988). Authenticity and commoditization in tourism. Annals of Tourism Research, 15(3), 371-386.

Cohen, E. (2006). Pai - a backpacker enclave in transition. Tourism Recreation Research, 31(3), 11-27.

Cohen, E. (2007). "Authenticity" in tourism studies: Aprés la lutte. Tourism Recreation Research, 32(2), 75-82.

Cohen, E. (2008a). Explorations in Thai tourism. Bingley, UK: Emerald. 
Cohen, E. (2008b). The tsunami waves and the paradisiac cycle: The changing image of the Andaman coastal region of Thailand. Tourism Analysis, 14(3), 221-232.

Cohen, E. (2009). Death in paradise: Tourist fatalities in the tsunami disaster in Thailand. Current Issues in Tourism, 12(2), 183-199.

Cohen, E. (2011). The people of tourism cartoons. Anatolia, 22(3), 323-349.

Cohen, E. (2012). Globalization, global crises and tourism. Tourism Recreation Research, 37(2), 1-9.

Cohen, E. \& Cohen, S.A. (2012). Authentication: Hot and cool. Annals of Tourism Research, 39(3), 1295-1314.

Cohen, S.A. (2011). Lifestyle travellers: Backpacking as a way of life. Annals of Tourism Research, 38(4), 1535-1555.

Cohen, S.A., Higham, J.E.S. \& Cavaliere, C.T. (2011). Binge flying: Behavioural addiction and climate change. Annals of Tourism Research, 38(3), 1070-1089.

Cole, S. (2012). A political ecology of water equity and tourism: A case study from Bali. Annals of Tourism Research, 39(2), 1221-1241.

Coles, T., Hall, C.M. \& Duval, D.T. (2006). Tourism and post-disciplinary enquiry. Current Issues in Tourism, 9(4-5), 293-319.

Collins-Kreiner, N. \& Gatrell, J.D. (2006). Tourism, heritage and pilgrimage: The case of Haifa's Bahá'í Gardens. Journal of Heritage Tourism, 1(1), 32-50.

Conran, M. (2011). They really love me! Intimacy in volunteer tourism. Annals of Tourism Research, 38(4), 1454-1473.

Cook, P.S. (2010). Constructions and experiences of authenticity in medical tourism: Performances of places, spaces, practices, objects and bodies. Tourist Studies, 10(2), 135-153.

Cunningham, H. (2007). Mobilities and enclosures after Seattle: Politicizing borders in a "borderless" world. Dialectical Anthropology, 33(2), 143- 156.

Daher, R.F. (2005). Urban regeneration/heritage tourism endeavours: The case of Salt, Jordan "local actors, international donors, and the state". International Journal of Heritage Studies, 11(4), 289-308.

Dann, G.M.S. \& Nordstrand, K.B (2009). Promoting wellbeing via multisensory tourism. In R. Bushell and P.J. Sheldon (Eds.) Wellness and Tourism (pp. 125137). New York: Cognizant Communication Corporation.

Drabek, T.E. (1986). Human System Responses to Disaster. New York: Springer.

Duval, D.T. (2003). When hosts become guests: Return visits and diasporic identities in a Commonwealth Eastern Caribbean community. Current Issues in Tourism, 6(4), 267-308.

Edensor, T. (1998). Tourists at the Taj: Performance and Meaning at a Symbolic Site. London: Routledge.

Edensor, T. (2001). Performing tourism, staging tourism. Tourist Studies, 1(1), 59-81. 
Edensor, T. (2007). Mundane mobilities, performances and spaces of tourism. Social \& Cultural Geography, 8(2): 199-215.

Edson, G. (2004). Heritage: Pride or passion, product or service? International Journal of Heritage Studies, 10(4), 333-348.

Eichhorn, V., Miller, G., Michopoulou, E. and Buhalis, D. (2008). Enabling access to tourism through information schemes? Annals of Tourism Research, 35(1), 189210.

Everett, S. (2009). Beyond the visual gaze? The pursuit of an embodied experience through food tourism. Tourist Studies, 8(3), 337-358.

Franklin, A. \& Crang, M. (2001). The trouble with tourism and travel theory? Tourist Studies, 1(1), 5-22.

Frost, W. (2004). Heritage tourism on Australia's Asian shore: A case study of Pearl Luggers, Broome. Asia Pacific Journal of Tourism Research, 9(3), 281-291.

Gale, T. (2009). Urban beaches, virtual worlds and "The End of Tourism." Mobilities, 4(1), 119-138.

Germann Molz, J. (2006). Cosmopolitan bodies: Fit to travel and travelling to fit. Body \& Society, 12(3), 1-21.

Goffman, E. (1959). The presentation of self in everyday life. New York: Anchor.

Goffman, E. (1974). Frame analysis: An essay on the organization of experience. New York: Harper and Row.

Gogia, N. (2006). Unpacking corporeal mobilities: The global voyages of labour and leisure. Environment and Planning A, 38(2), 359-375.

Goodwin, H. (2008). Pro-poor tourism: a response. Third Word Quarterly, 29(5), 869871.

Gössling, S. (2002). Human-environmental relations with tourism. Annals of Tourism Research, 29(2), 539-556.

Gössling, S. \& Nilsson, J.H. (2010). Frequent flyer programmes and the reproduction of aeromobility. Environment and Planning A, 42, 241-252.

Gössling, S., Scott, D., Hall, C.M., Ceron, J.-P., Dubois, G. (2012). Consumer behaviour and demand response of tourists to climate change. Annals of Tourism Research, 39(1), 36-58.

Graburn, N. (1977). Tourism: The sacred journey. In V. Smith (Ed.), Hosts and guests (pp. 17-31). Philadelphia: University of Pennsylvania Press.

Gren, A. \& Huijbens, E.H. (2012). Tourism theory and the Earth. Annals of Tourism Research, 39(1), 155-170.

Hall, C.M. (2007). Pro-poor tourism: Do 'tourism exchanges benefit primarily the countries of the south'? Current Issues in Tourism, 10(2-3), 111-118.

Hall, C. M. \& Müller, D. K. (2004). Tourism, mobility and second homes: Between elite landscapes and common ground. Toronto: Channel View. 
Haldrup, M. (2004). Laid-back mobilities: Second-home holidays in time and space. Tourism Geographies, 6(4), 434-454.

Hannam, K. (2008). Tourism geographies, tourist studies and the turn towards mobilities. Geography Compass, 2(1), 127-139.

Hannam, K., Sheller, M. \& Urry, J. 2006. Editorial: Mobilities, immobilities, moorings. Mobilities, 1(1), 1-22.

Harrison, D. (2008). Pro-poor tourism: A critique. Third World Quarterly, 29(5), 851868.

Harvey, D.C. (2001). Heritage pasts and heritage presents: Temporality, meaning and the scope of heritage studies. International Journal of Heritage Studies, 7(4), 319338.

Healy, R.G. (2006). The commons problem and Canada's Niagara Falls. Annals of Tourism Research, 33(2), 525-544.

Henderson, J.C. (2005). Responding to natural disasters: Managing a hotel in the aftermath of the Indian Ocean tsunami. Tourism and Hospitality Research, 6(1), 89-96.

Higgins-Desbiolles, F. (2006). More than an 'industry': The forgotten power of tourism as a social force. Tourism Management, 27(6), 1192-1208.

Hitchcock, M., King, V.T. \& Parnwell, M. eds. (2010). Heritage Tourism in Southeast Asia. Copenhagen: NIAS.

Hjarvard, S. (2008). The mediatization of society. Nordicom Review, 29(2), 105-134.

Hoffman, S. \& Oliver-Smith, A. (1999). Anthropology and the angry earth: An overview. In A. Oliver-Smith \& S. Hoffman (Eds.), The Angry Earth; Disaster in Anthropological Perspective (pp. 1-16). New York: Routledge.

Holden, A. (2009). The environment-tourism nexus: Influence of market ethics. Annals of Tourism Research, 36(3), 373-389.

Holloway, D., Green, L. \& Holloway, D. (2011). The intratourist gaze: Grey nomads and 'other tourists'. Tourist Studies, 11(3), 235-252.

Huan, T.-Ch., Beaman, J. \& Shelby, L. (2004). No-escape natural disaster: Mitigating impacts on tourism. Annals of Tourism Research, 31(2), 255-273.

Hui, A. (2009). Many homes for tourism. Tourist Studies, 8(3), 291-311.

Hystad, P.W. \& Keller, P.C. (2008). Towards a destination tourism disaster management framework: Long-term lessons from a forest fire disaster. Tourism Management, 29(1), 151-162.

Ichinosawa, J. (2006). Reputation disaster in Phuket: The secondary impact of the tsunami on inbound tourism. Disaster Prevention and Management, 15(1), 111123.

Jansson, A. (2002). Spatial phantasmagoria. European Journal of Communication, 17(4), 429-443.

Jamal, T. \& Kim, H. (2005). Bridging the interdisciplinary divide: Towards an integrated framework for heritage tourism research. Tourist Studies, 5(1), 55-83. 
Janta, H., Brown, L., Lugosi, P. \& Ladkin, A. (2011). Migrant relationships and tourism employment. Annals of Tourism Research, 38(4), 1322-1343.

Jenkins O. (2003). Photography and travel brochures: The circle of representations. Tourism Geographies, 5(3), 305-328.

Jensen, J.L. (2010). Online tourism: just like being there? In B.T. Knudsen \& A.M. Waade (Eds.) Re-investing authenticity: Tourism, place and emotions (pp. 213225). Bristol: Channel View.

Jensen, J.L. \& Waade, A.M. (2009). Medier og turisme. Århus: Academica.

Jensson, A. (2002). Spatial phantasmagoria: The mediatization of tourism experience. European Journal of Communication, 17(4), 429-443.

Jóhannesson, G. T. (2005). Tourism translations: Actor-network theory and tourism research. Tourist Studies, 5(2), 133-150.

Johnston, L. (2001). (Other) bodies and tourism studies. Annals of Tourism Research, 28(1), 180-201.

Kirschenblatt-Gimblett, B. (1998). Destination culture: Tourism, museums, and heritage. Berkeley: University of California Press.

Knudsen, B.T. and A.M. Waade, eds. (2010). Re-investing authenticity: Tourism, place and emotions. Bristol: Channel View.

Kousis, M. (2000). Tourism and the environment: A social movements perspective. Annals of Tourism Research, 27(2), 468-489.

Lagerkvist, A. (2007). Gazing at Pudong - "with a drink in your hand": Time travel, mediation, and multisensuous immersion in the future city of Shangai. The Senses and Society 2(2), 155-172.

Lagerkvist, A. (2008). Travels in thirdspace: Experiential suspense in mediaspace the case of America (Un)known. European Journal of Communication, 23(3), 343-363.

Landorf, C. (2009). Managing for sustainable tourism: A review of six cultural World Heritage Sites. Journal of Sustainable Tourism, 17(1), 53-70.

Larsen, J. (2008). De-exoticizing tourist travel: Everyday life and sociality on the move. Leisure Studies, 27(1), 21-34.

Latour, B. (2005). Reassembling the social. Oxford: Oxford University Press.

Laws, E. \& Prideaux, B., eds. (2005). Tourism Crises: Management Responses and Theoretical Insights. Binghamton: Haworth Hospitality.

Li, M., Wu, B. \& Cai, L. (2008). Tourism development of World Heritage Sites in China: A geographic perspective. Tourism Management, 29(2), 308-319.

Logan, W.S. (2001). Globalizing heritage: World heritage as a manifestation of modernism and challenges from the periphery. In Proceedings of Australia ICOMOS National Conference 2001: $20^{\text {th }}$ Century Heritage - Our Recent Cultural Legacy (pp. 51-57). Adelaide 28 November - 1 December 2001.

Lowenthal, D. (2005). Natural and cultural heritage. International Journal of Heritage Studies, 11(1), 81-92. 
Macbeth, J. (2005). Towards an ethics platform for tourism. Annals of Tourism Research, 32(4), 962-984.

MacCannell, D. (1973). Staged authenticity: Arrangements of social space in tourist settings. American Journal of Sociology, 79(3), 589-603.

MacCannell, D. (1976). The Tourist: A New Theory of the Leisure Class. New York: Schocken Books.

Månsson, M. (2010). Negotiating authenticity at Rosslyn Chapel. In B.T. Knudsen \& A.M. Waade (Eds.) Re-investing authenticity: Tourism, place and emotions. (pp. 169-180). Bristol: Channel View.

Månsson, M. (2011). Mediatized tourism. Annals of Tourism Research, 38(4), 16341652.

Maoz, D. (2006). The mutual gaze. Annals of Tourism Research, 33(1), 221-239.

McCabe, S. (2009). Who needs a holiday? Evaluating social tourism. Annals of Tourism Research, 36(4), 667-688.

McMorran, C. (2008). Understanding the "heritage" in heritage tourism: Ideological tool or economic tool for a Japanese hot spring resort? Tourism Geographies, $10(3), 334-354$.

Minnaert, L., Maitland, R. \& Miller, G. (2009). Tourism and social policy: The value of social tourism. Annals of Tourism Research, 36(2), 316-334.

Minnaert, L., Maitland, R. \& Miller, G. (2011). Editorial: What is social tourism? Current Issues in Tourism, 14(5), 403-415.

Miller, G., Rathouse, K., Scarles, C., Holmes, K. \& Tribe, J. (2010). Public understanding of sustainable tourism. Annals of Tourism Research, 37(3), 627645.

Miura, K. (2010). World Heritage Sites in Southeast Asia: Angkor and beyond. In M. Hitchcock, V.T. King \& M. Parnwell (Eds.), Heritage tourism in Southeast Asia (pp. 103-129). Copenhagen: NIAS.

Modlin, E.A., Alderman, D.H. \& Gentry, G.W. (2011). Tour guides as creators of empathy: The role of affective inequality in marginalizing the enslaved at plantation house museums. Tourist Studies, 11(1), 3-19.

Nash, D. (2007). The study of tourism: Anthropological and sociological beginnings. Oxford: Elsevier.

Ness, S.A. (2005). Tourism-terrorism: The landscaping of consumption and the darker side of place. American Ethnologist, 32(1), 118-140.

Nuryanti, W. (1996). Heritage and postmodern tourism. Annals of Tourism Research, 23(2), 249-260.

Nyaupane, G.P. \& Poudel, S. (2011). Linkages among biodiversity, livelihood, and tourism. Annals of Tourism Research, 38(4), 1344-1366.

Obrador Pons, P. (2003). Being-on-holiday: Tourist dwelling, bodies and place. Tourist Studies, 3(1), 47-66. 
Obrador Pons, P. (2009). Building castles in the sand: Repositioning touch on the beach. The Senses \& Society, 4(2), 195-210.

Obrador Pons, P., \& Carter, S. (2010). Art, politics, memory: Tactical Tourism and the route of anarchism in Barcelona. Cultural Geographies, 17(4), 525-531.

Oliver-Smith, A. \& Hoffman, S.N., eds. (2002a). Catastrophe \& Culture: The anthropology of disaster. Oxford: James Currey.

Oliver-Smith, A. \& Hoffman, S.N. (2002b). Introduction: Why anthropologists should study disaster. In S.N. Hoffman \& A. Oliver-Smith (Eds.) Catastrophe \& Culture: The anthropology of disaster (pp. 3-22). Oxford: James Currey.

Olsen, K. (2002). Authenticity as a concept in tourism research. Tourist Studies, 2(2), 159-182.

Ooi, C.-S. \& Stöber, B. (2010). Authenticity and place branding: The arts and culture in branding Berlin and Singapore. In B.T. Knudsen \& A.M. Waade (Eds.) Reinvesting authenticity: Tourism, place and emotions (pp. 66-79). Bristol: Channel View.

Paget, E., Dimanche, F. \& Mounet, J.-P. (2010). A tourism innovative case: An actornetwork approach. Annals of Tourism Research, 37(3), 828-847.

Paris, C. (2012). Flashpackers: An emerging sub-culture? Annals of Tourism Research, 39(2), 1094-1115.

Pearce, P. (2012). The experience of visiting home and familiar places. Annals of Tourism Research, 39(2), 1024-1047.

Pezzullo, P.C. (2009). "This is the only tour that sells": Tourism, disaster, and national identity in New Orleans. Journal of Tourism and Cultural Change, 7(2), 99-114.

Poon, A. (1993). Tourism, technology and competitive strategies. Wallingford: CABI.

Poria, Y., Reichel, A. \& Biran, A. (2006). Heritage site perceptions and motivations to visit. Journal of Travel Research, 44(3), 318-324.

Porter, B.W. \& Salazar, N.B. (2005). Heritage tourism, conflict, and the public interest: An introduction. International Journal of Heritage Studies, 11(5), 361370 .

Pritchard, A., Morgan, N. \& Ateljevic, I. (2011). Hopeful tourism: A new transformative perspective. Annals of Tourism Research, 38(3), 941-963.

Rakic, T. \& Chambers, D. (2012). Rethinking the consumption of places. Annals of Tourism Research, 39(3), 1612-1633.

Reisinger, Y. \& Steiner, C.J. (2006). Reconceptualizing object authenticity. Annals of Tourism Research, 33(1), 65-86.

Ren, C. (2011). Non-human agency, radical ontology and tourism realities. Annals of Tourism Research, 38(3), 858-881.

Ritchie, B.W. (2004). Chaos, crises and disasters: A strategic approach to crisis management in the tourist industry. Tourism Management, 25(6), 669-683. 
Ritchie, B.W. (2009). Crisis and Disaster Management for Tourism. Bristol: Channel View.

Rittichainuwat, N. (2008). Responding to disaster: Thai and Scandinavian tourists' motivation to visit Phuket, Thailand. Journal of Travel Research, 46(4), 422-432.

Rittichainuwat, N. (2011). Ghosts: A travel barrier to tourism recovery. Annals of Tourism Research, 38(2), 437-459.

Ritzer, G. \& Liska, A. (1997). McDisneyization and 'Post-Tourism": Complementary perspectives on contemporary tourism. In C. Rojek \& J. Urry (Eds.), Touring Cultures: Transformations of Travel and Theory (pp. 96-109). London: Routledge.

Rodger, K., Moore, S.A. \& Newsome, D. (2009). Wildlife tourism, science and actor network theory. Annals of Tourism Research, 36(4), 645-666.

Saarinen, J. (2006). Traditions of sustainability in tourism studies. Annals of Tourism Research, 33(4), 1121-1140.

Scarles, C. (2010). Where words fail, visuals ignite: Opportunities for visual autoethnography in tourism research. Annals of Tourism Research, 37(4), 905926.

Scholte, J.A. (2000). Globalization: A critical introduction. London: Palgrave.

Sedgley, D., Pritchard, A. \& Morgan, N. (2011). Tourism and ageing: A transformative research agenda. Annals of Tourism Research, 38(2), 422-436.

Sherlock, K. (2001). Revisiting the concept of hosts and guests. Tourist Studies, 1(3), 271-295.

Small, J. and Harris, C. (2012). Obesity and tourism: Rights and responsibilities. Annals of Tourism Research, 39(2), 686-707.

Sönmez, S.F. (1998). Tourism, terrorism and political instability. Annals of Tourism Research, 25(2), 416-456.

Steiner, C.J. \& Reisinger, Y. (2006). Understanding existential authenticity. Annals of Tourism Research, 33(2), 299-318.

The Nation (2012, 17 Feb). Editorial: Officials need to wake up and admit the truth. Retrieved 2 March 2012, from <http://www.nationmultimedia.com/opinion/Officials-need-to-wake-up-andadmit-the-truth-30176045.html>.

Thrift, N. (1997). The still point: Resistance, expressive embodiment and dance. In S. Pile \& M. Keith (Eds.), Geographies of Resistance (pp.124-151). London: Routledge.

Thrift, N. (2004). Intensities of feeling: Towards a spatial politics of affect. Geografiska Annaler: Series B, Human Geography, 86(1), 57-78.

Tierney, K.J. (2007). From the margins to the mainstream? Disaster research on the crossroads. Annual Review of Sociology, 33, 503-525.

Timothy, D.J. \& Prideaux, B. (2004). Issues in heritage and culture in the Asia Pacific region. Asia Pacific Journal of Tourism Research, 9(3), 213-223. 
Timothy, D.J. \& Boyd, S.W. (2006). Heritage tourism in the $21^{\text {st }}$ century: Valued traditions and new perspectives. Journal of Heritage Tourism, 1(1), 1-16.

Tribe, J. (2010). Tribes, territories and networks in the tourism academy. Annals of Tourism Research. 37(1), 7-33.

Tung, V.W.S. \& Ritchie, J.R.B. (2011). Exploring the essence of memorable tourism experiences. Annals of Tourism Research, 38(4), 1367-1386.

Tussyadiah, I.P. \& Fesenmaier, D.R. (2009). Mediating tourist experiences: Access to places via shared videos. Annals of Tourism Research, 36(1), 24-40.

Uriely, N. (2005). The tourist experience. Conceptual developments. Annals of Tourism Research, 32(1), 199-216.

Urry, J. (1990). The Tourist Gaze: Leisure and Travel in Contemporary Societies. London: Sage.

Urry, J. (2000). Mobile sociology. British Journal of Sociology, 51(1), 185-203.

Urry, J. (2007). Mobilities. Cambridge: Polity Press.

Valkonen, J. (2010). Acting in nature: Service events and agency in wilderness guiding. Tourist Studies, 9(2), 164-180.

Valtonen, A. \& Veijola, S. (2011). Sleep in tourism. Annals of Tourism Research, $38(1), 175-192$.

van der Duim, R. (2007). Tourismscapes: An actor-network perspective. Annals of Tourism Research, 34(4), 961-976.

Van der Duim, R., Ren, C., Jóhannesson, G.T. (2012). Actor-network theory and tourism: Ordering, materiality and multiplicity. London: Routledge.

Vecco, M. (2010). A definition of cultural heritage: from the tangible to the intangible. Journal of Cultural Heritage, 11(3), 321-324.

Veijola, S. \& Jokinen, E. (1994). The body in tourism. Theory, Culture \& Society, 11, $125-151$.

Waitt, G. (2000). Consuming heritage: Perceived historical authenticity. Annals of Tourism Research, 27(4), 835-862.

Waitt, G. \& Duffy, M. (2010). Listening and tourism studies. Annals of Tourism Research, 37(2), 457-477.

Wang, N. (1999). Rethinking authenticity in tourism experience. Annals of Tourism Research, 26(2), 349-370.

Wang, N. (2000). Tourism and modernity: A sociological analysis. Oxford: Pergamon Press.

Waterton, E. (2009). Sights of sites: Picturing heritage, power, and exclusion. Journal of Heritage Studies, 4(1), 37-56.

Weaver, B. (2011). Can sustainable tourism survive climate change? Journal of Sustainable Tourism, 19(1), 5-15. 
Wheeller, B. (1993). Sustaining the ego. Journal of Sustainable Tourism, 1(2), 121129.

White, N.R. \& White, P.B. (2007). Home and away: Tourists in a connected world. Annals of Tourism Research, 34(1), 88-104.

Winter, T. (2009). Asian tourism and the retreat of anglo-western centrism in tourism theory. Current Issues in Tourism, 12(1), 21-31.

Yau, M.K., McKercher, B. \& Packer, T.L. (2004). Traveling with a disability: More than an access issue. Annals of Tourism Research, 31(4), 946-960. 